Interfaces

\title{
Reunion, a Novella by Fred Uhlman (1971) adapted to the Cinema by Harold Pinter for Jerry Schatzberg (1989): from (auto)biography to politics
}

Isabelle Roblin

\section{OpenEdition}

\section{Journals}

Electronic version

URL: http://journals.openedition.org/interfaces/298

DOI: $10.4000 /$ interfaces. 298

ISSN: 2647-6754

Publisher:

Université de Bourgogne, Université de Paris, College of the Holy Cross

\section{Printed version}

Date of publication: 1 January 2016

Number of pages: 163-179

ISSN: 1164-6225

\section{Electronic reference}

Isabelle Roblin, "Reunion, a Novella by Fred UhIman (1971) adapted to the Cinema by Harold Pinter for Jerry Schatzberg (1989): from (auto)biography to politics", Interfaces [Online], 37 | 2016, Online since 19 March 2018, connection on 06 January 2021. URL: http://journals.openedition.org/interfaces/298 : DOI: https://doi.org/10.4000/interfaces.298

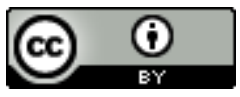

Les contenus de la revue Interfaces sont mis à disposition selon les termes de la Licence Creative Commons Attribution 4.0 International. 


\title{
REUNION, A NOVELLA BY FRED UHLMAN (1971) ADAPTED TO THE CINEMA BY HAROLD PINTER FOR JERRY SCHATZBERG (1989): FROM (AUTO)BIOGRAPHY TO POLITICS
}

\author{
Isabelle Roblin
}

Before starting on the analysis of the ways in which Harold Pinter and Jerry Schatzberg transformed and re appropriated Fred Uhlman's text to make it into a film, it is necessary to sum up what the text is about. The plot of Uhlman's largely autobiographical novella is quite simple. It is about the short and intense, but ultimately impossible, friendship between two fifteen-year-old school boys during the rise of the Nazi party in Stuttgart in the early 1930s, and more exactly between February 1932 and January 1933. Hans Schwarz, the first-person narrator, is the son of a well-integrated Jewish doctor who fought in WWI and is proud of being German. Konradin von Hohenfels is a young aristocrat, the son of an ambassador and "a member of [an] illustrious Swabian family" (Uhlman 19). At first, Hans and Konradin manage to become close friends despite their differences and spend their weekends together in the spring of 1932 exploring the Black Forest, the Danube and the Hegau (Uhlman 36-39) and talking about literature, God and girls. However, "the rise of the National Socialist Party intrudes on the lives of the two boys more and more" (Gale 305). Konradin soon has to tell Hans that his mother and most of his family hate Jews, and both realise it is the beginning of the end of their friendship and of their carefree childhood (Uhlman 90). As the situation deteriorates, Hans' parents decide to send him to the United States to live with his relatives while they commit suicide by gassing themselves as a result of Nazi persecution, thus anticipating the fate of millions of Jews gassed in Nazi extermination camps. Hans becomes a successful lawyer in New York, with “"everything' - an apartment overlooking Central Park, cars, a place in the country [...] and so on" (Uhlman 104-105). He tries to forget his past. However, the events he has been relating come back to him when, thirty years later, "out of the blue," he receives a booklet with a list of names and an appeal from the Karl Alexander Gymnasium, his former high school in Stuttgart, asking him "to subscribe for a war memorial to the boys who had fallen in the Second World War" (Uhlman 109). The story ends as, just before throwing the booklet away, Hans decides to look at the letter " $H$ " and discovers that Konradin von Hohenfels was executed by the Nazis after his participation in the failed assassination attempt against Hitler in July 1944.

When he was asked by Anne François, the film's producer, to adapt Fred Uhlman's novella for Jerry Schatzberg, Harold Pinter had already written twelve screenplays. Moreover, he had already 
read the book, and liked it very much. However, he was aware from the start that he would have first to reappropriate it and make quite a few changes to make it into a film. Novellas are too short to be turned into a standard 110 minutes' film. Adapting a short story or a novella is thus very different from scripting a novel, where cutting and concentrating narrative elements usually are the screenwriter's top priorities. Taking as his starting point the categories created by John Desmond and Peter Hawkes in Adaptation: Studying Film and Literature (2005), Thomas Leitch notes: "Cinematic adaptations of short stories $[\ldots]$ can expand their material to feature length by one of three strategies." The first one, called 'the concentration strategy' by Desmond and Hawkes, "begins by following [the short-story] almost line by line before going off for the rest of its length in a completely new direction." The second one, "the 'interweaving strategy', retain[s] the leading elements of the story at hand but disperse[s] those elements throughout the film [...] and interweave[s] either invented elements or expansions on already existing elements." In the third one, "the point of departure strategy', "the filmmakers drop most of the narrative elements from the short story $[\ldots]$ and $[. .$.$] invent a new story based on the remaining elements"$ (69). When he wrote the script for Reunion for Jerry Schatzberg, Harold Pinter, as in the other novellas and short stories he adapted throughout his long career as a screenwriter (The Servant, The Comfort of Strangers and the short-story "The Dreaming Child"), clearly chose the second strategy. He kept the main elements from the source novella but fleshed them out by inventing new episodes and characters and adding whole sequences, thereby appropriating it and transforming it considerably (Roblin 114-115). On top of the technical reasons for these changes to the narrative structure of Uhlman's text he also added his personal touch when rewriting the dialogues, for example, but also included a more political take on the situation in Germany in the late 1980s regarding its Nazi past.

These changes can be studied by comparing the novella to the published shooting script, but also to the earlier manuscript versions of the screenplay which are kept at the British Library (MS88880/2/95-101). The film closely follows the published screenplay, with only "the deletion of small scenes or shots that might have been considered merely duplicative during the editing process and the rearranging of the order of a few scenes or lines of dialogues" (Gale 309). This was due to the close collaboration of the director and screenwriter, who worked together on the script from the start (Schatzberg qtd. in Gauthier, Viva Pinter 67-73). An example of a minor difference between the screenplay and the film can be found at the beginning: Henry's young granddaughter Alex is charged while playing in Central Park by "two large dogs" in Pinter's script (536), but in the film there is only one dog, clearly a German Shepherd: the hint is not very subtle and I for one think that Schatzberg somewhat laboured the point. Another German Shepherd however features shortly afterwards in a black-and-white shot of Henry's father, standing to attention in his WWI uniform, next to a member of the SS holding 
an anti-Jewish placard in his right hand and a fierce-looking German Shepard on leash in the other. The parallel between the two situations for Henry is made clear through the dog as the incident with his granddaughter has triggered an unwelcome and sad memory (see illustrations 1 and 2).

Some of the changes from the novella to the screenplay and the film are quite revealing, such as the adult Hans's first name being turned into Henry and his family name transformed from 'Schwarz' to 'Strauss,' epitomizing his rejection of everything German: as the narrator says in Uhlman's novella,

since [my parents'] death I have as far as possible avoided meeting Germans and haven't opened a single German book, not even Hölderlin [...]. Of course I can still speak the language perfectly well, allowing for my American accent, but I dislike using it. My wounds have not healed, and to be reminded of Germany is to have salt rubbed into them (107).

This is echoed and even taken further in Pinter's screenplay when Henry tells the headmaster of the Karl Alexander Gymnasium "I haven't read a German book or a German newspaper. I haven't spoken a word of the German

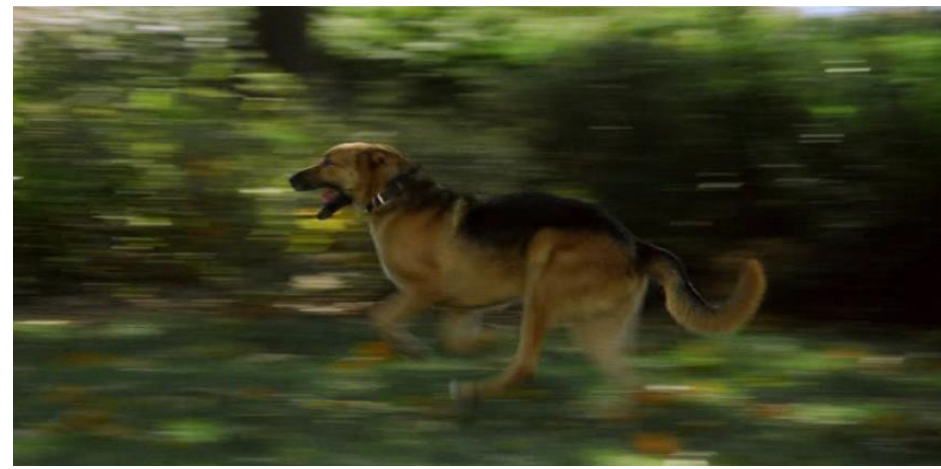

Illustration 1: 1987, Henry's young grand-daughter Alex is charged while playing in Central Park by a large German Shepherd

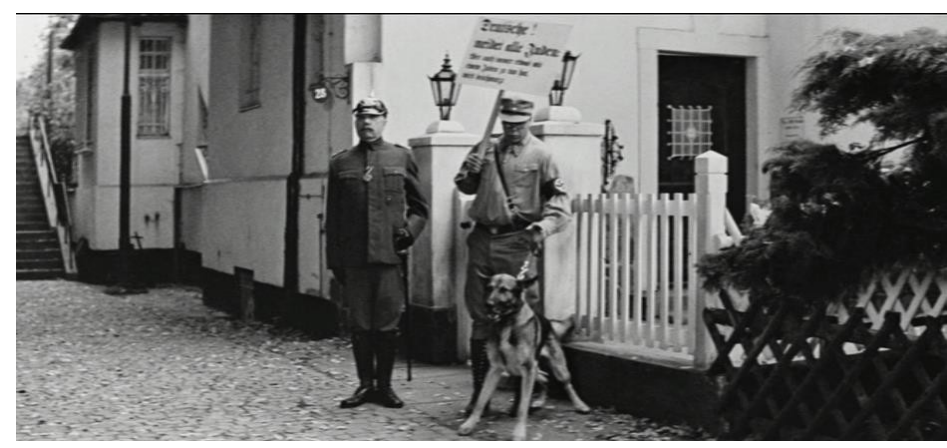

Illustration 2: 1932, Henry's father, standing at attention in his WWI uniform, next to a member of the SS holding an anti-Jewish placard in his right hand and a fierce-looking German Shepherd on leash in the other (black and white) 
language ... in all that time" (608). Pinter also for some (unexplained) reason changed Konradin's name from "von Hohenfels" to "von Lohenburg." Other changes however were more substantial.

Uhlman's first-person narrative novella is made up of nineteen short to very short chapters. It starts with the narrator remembering the day Konradin entered the classroom and the narrator's life for the first time, in February 1932, never to leave it again, as he says (11). Out of the 19 chapters, the first 17 cover one year in the life of Hans and Konradin, specifically dated (Feb 1932-Jan 1933), and the last 2 chapters are set in the narrative present in New York, with Hans telling his story thirty years later in a long analepsis. The most important changes to this narrative structure were agreed upon from the start by Schatzberg and Pinter. The first decision they made was that there was to be no voice-over to narrate the story. Schatzberg explained in an interview that he dislikes voice-overs in films, which he finds uncinematic (qtd. in Gauthier, Viva Pinter 68). Pinter himself repeatedly spoke out against voice-overs throughout his career as a screenwriter, criticising some of the Nouvelle Vague directors for refusing to find cinematic equivalents to first person narratives of their adapted texts, like François Truffaut in Jules et Jim (1962), where the director himself reads whole passages from Henri-Pierre Roché's 1953 source novel. In an interview with Michael Billington, his biographer, Pinter made his dislike of this technique, which he considered as a form of affected mannerism, quite clear: "One thing I don't like about French cinema as it developed was what seemed to me to be a very self-conscious commentary on the images and what we were actually seeing - on the tale being told. [...] I think most first-person narrative which illustrates what you are actually looking at is redundant" (Various Voices 71).

The second narrative change is even more fundamental: feeling that keeping the older Henry/ Hans in his office in New York, reading old papers and remembering everything in a long, linear flashback would be too static, Pinter and Schatzberg decided to make it more dynamic by taking Henry/ Hans back to Germany for the first time in fifty-five years. In the novella, Hans has been in America for thirty years when he writes his story (Uhlman 104), which can thus be dated to the early 1960s. By extending the time lapse between Hans/Henry leaving Germany for New York and discovering what happened to Konradin to fifty-five years, Pinter makes the story contemporary with the release of the film in in the late 1980s. Another reason might be that Pinter's adaptation of The Quiller Memorandum, which is a spy novel about the resurgence of Nazism in Germany, is set during the 1960s. Clearly by the 1980s Pinter wanted to show his continuing preoccupation with "the enigmatic dualism within the German psyche and about the pressures that led the country to elect Hitler democratically to power" (Billington 316$)^{1}$ as well as his concern about forgetting the Nazi past. Thus Hans/Henry goes back

Pinter gives another, more practical explanation as to why Schatzberg and he had decided not to make Henry/Hans return in the 1960s: «nous aurions eu deux périodes en costumes [...]. Il n'y avait aucune raison pour que cela ne se passe pas aujourd'hui. Il a été à l'écart de tout cela pour plus longtemps et lui faire entreprendre ce retour en Allemagne à cet âge rend l'expérience encore plus intense » (Ciment, « Entretien avec Harold Pinter », 26). 
to Germany, theoretically to dispose of his parents' belongings, which had been held in storage in a warehouse in Stuttgart since the 1930s. The fact that it is but a pretext is made obvious in the published script and the film by the following dialogue with his daughter Lisa, another character invented by Pinter, who provided Henry with a loving family:

\section{INT. NEW YORK RESTAURANT. DAY. $[\ldots]$}

LISA: You don't have to go. You don't want to go. Why are you going?

HENRY: I have to take care of this ... thing.

LISA: You could do it from here. You know that. Your secretary could do it for you. I could do it for you. You don't have to go all the way over there yourself. Do you? What's the point? HENRY: I want to do it myself. I have to go and do it myself. (538)

Once in Stuttgart, Henry quickly disposes of his parents' possessions: "It's all in very good condition. [...] I want you to sell it and I want the money to go to charity" (547), he tells the warehouse-keeper. As Brigitte Gauthier points out, the fact that Henry donates the proceeds to a charity for the Blind

might be a deliberate indication of our psychological and political blindness regarding the most important issues: here the scope of budding Nazism in Germany. Hans' parents wanted to stick to their German Jewish identity. His father was proud of having fought for Germany; once he understood that this double belonging would be refused to him, he sent his son to the USA, and committed suicide with his wife. (The Caretaker of the Fragments of Modernity 86-7)

But then the real purpose of his visit becomes progressively clearer. He drives to his old house (603-4) and to the cemetery to find his parents' grave (605-6). And next he goes to where Konradin's stately home used to be, to discover that it is now "a house for income taxes. Special income taxes department of Stuttgart" (597), whereas in the novella the narrator learns from "a man from Württemberg" he had met in New York that "the Palais Hohenfels" was now "rubble" (108). Charles Grimes sees in "the notion that the Lohenberg's house has become a tax office" an allusion "to Germany's postwar 'economic miracle' [Wirtschaftswunder], which has been suggested as one of the conditions making it easy for Germany to forget [ignore? repress?] the enormity of its past" (Harold Pinter's Politics 181).

Contrary to Uhlman's narrator, the filmic Henry/Hans wants to find out what has happened to his former friend and starts to investigate. He first unsuccessfully tries to get some information from a cousin of Konradin's, Gertrude, Gräfin von Zeilarn und Lizen, (a character invented by Pinter) whom he had been introduced to by Konradin in 1932: 


\section{INT. ZEILARN HOUSE. DAY}

$[\ldots]$

HENRY: This is my first visit to Germany... for fifty-five years.

GRÄFIN: And what can I do for you?

Pause.

HENRY: I was a close friend of Konradin von Lohenburg.

GRÄFIN: Were you?

HENRY: I don't know what happened to him. I would like to know what happened to him. Did he survive the war? Do you know ... Madame? Can you tell me?

She stands.

GRÄFIN: It is not a subject I am willing to discuss. I trust you will find your visit to Germany of interest. Please excuse me.

She inclines her head and leaves the room.

He remains standing. (602)

Eventually, he finds the new Karl Alexander Gymnasium, the old one having been bombed, in keeping with the novella ("What happened to the Karl Alexander Gymnasium?" Hans asks the same man from Württemberg. "“Rubble,' he said” 108). There the headmaster, Herr Brossner, finally reveals what happened to Konradin as past and present merge on the screen, finally making sense of the opening shots at the beginning of the film:

\section{EXT. SCHOOL TERRACE. DAY.}

$[\ldots]$

Attached to the wall a large war memorial, containing over one hundred names.

Henry stands, looking at it.

$[\ldots]$

Henry looks at the list of names beginning with L. There he sees 'Konradin von Lohenburg'. He turns to Brossner.

HENRY: And Lohenburg?

Brossner stares at him. 
BROSSNER: Lohenburg?

\section{INT. EMPTY EXECUTION ROOM. DAY.}

The room is bare. Two windows at the back. Winter sunshine slanting in. A rafter along the ceiling in front of the window. Butcher's hooks hanging down.

Over this Brossner's voice.

BROSSNER (VO): You don’t know? He was implicated in the plot against Hitler. Executed.

The butcher's hooks glint in the light from the window. (608-609)

This closing scene is indeed to be considered in parallel with the opening ones of a prison yard (1) and the execution room (2). The stage directions are the same: "The room is bare. Two windows at the back. Winter sunshine slanting in. A rafter along the ceiling in front of the window, " and from the start prepared the ground for the final revelation of Konradin's fate. The only, and of course, crucial, difference between scene two and the last one is that in between, the execution by hanging from the butcher's hooks of the prisoners who filed in and stood against the wall in scene 2, whom we now know are the participants in the failed assassination plot against Hitler in July 1940, is over and they are all dead. The last word in the novella, the published screenplay and the film is the same: "Executed" (see illustrations 3 and 4).

In earlier versions of the screenplay, Pinter had added another scene, which lessened the emotional impact of the execution scene, by having Henry on the plane flying back to New York and "look[ing] out of the window at Germany disappearing below." As Schatzberg said in an interview,

we had diverging views on emotions. Pinter didn't want to have emotions. [...] I think we had one disagreement and that was about the end of the film. I had one point of view. He had another point of view and we talked about it a lot. And finally in the end I said, 'Harold, why don't you write both endings, I'll shoot both endings, and I'll shoot them both as well as I can, if your ending turns out to be better, it will have to be good,' and we did it that way, I looked at both endings when I was doing it and obviously when I was cutting the film. I felt that my ending was what it should be, so I put it in. He came to Paris, looked at the cut, and he came

2 Shot 117 of the screenplay of Fred Uhlman's Reunion, dated February 22, 1988. British Library, ADD MS88881/8/14 


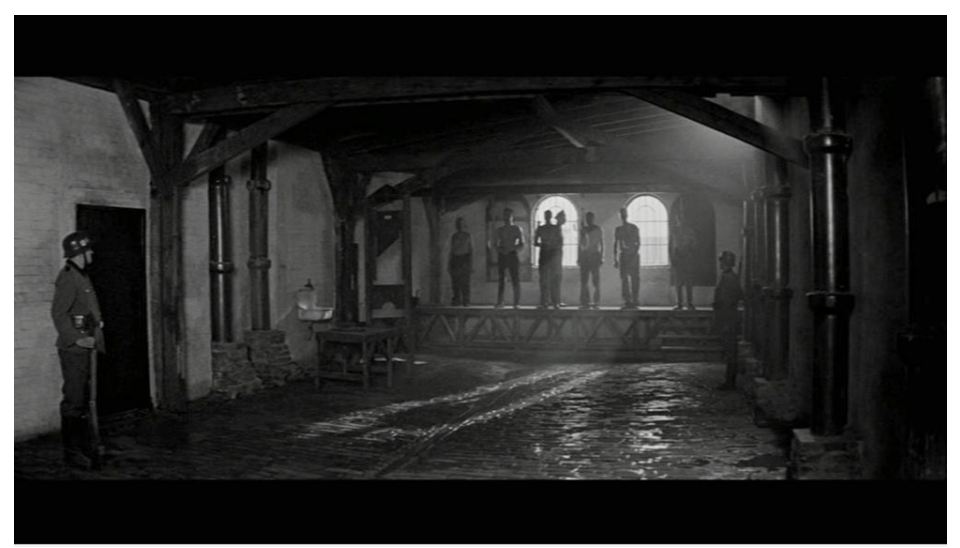

Illustration 3: opening shot: the execution room (black and white)

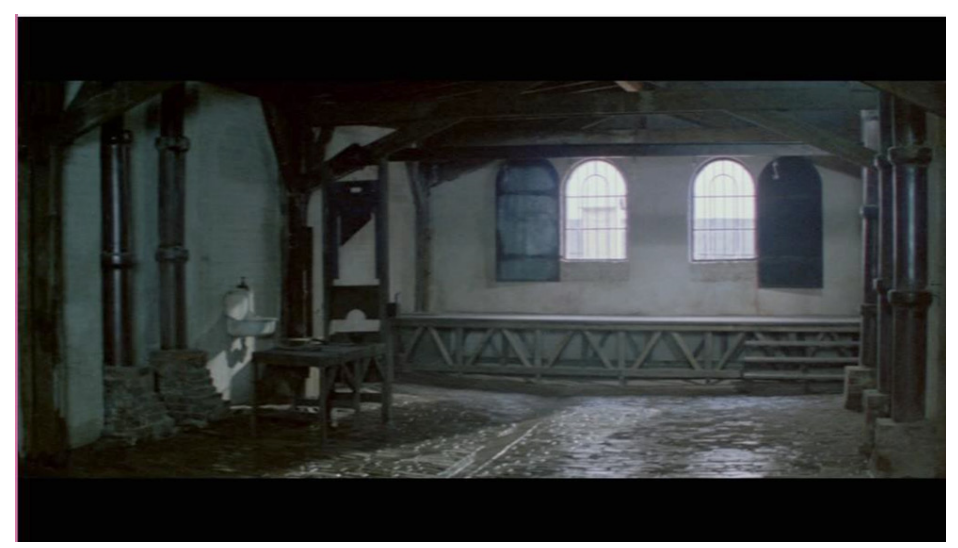

Illustration 4: final shot: the empty execution room (colour) out and he was just delighted... (qtd. in Gauthier, Viva Pinter $68,69)$.

In his brief introduction to the published screenplay, Pinter explains that the succession of invented scenes made necessary by Henry's return to Germany is used to "juxtapose[] past and present, gradually revealing both" (introduction to Collected Screenplays 2 ix). Instead of a straightforward, linear narrative, "the painful mosaic of the past is reassembled as the film progresses" (Knowles 171) by using the same technique Pinter had used in his adaptations of Conrad's Victory and in The Proust Screenplay (both unfilmed to this day). It starts with what Knowles calls a "proleptic serial montage" (171) of various short and apparently unrelated shots that anticipate what is to come. The two opening shots in black and white of a prison yard and an execution room I have been discussing above are followed by silent shots of "a little girl on a swing" dated 1932 and then of a schoolroom (also dated 1932) as Konradin enters and Hans (Henry when sixteen) looks up (535). The fifty-five years separating the past and the present then progressively merge as 'Sounds of Central Park gradually grow on the soundtrack. 
Barking dogs" and the next shot is that of a summer day in 1987, with Henry, 70, sitting on a park bench as a large dog knock down his grand-daughter (536):

From the first moment, therefore, Pinter creates a threat that exists beyond each shot. And within the overall structure of the screenplay something stands out, for while the little girl on the swing, the scene in the classroom, and the scene in Central Park all have a context within the narrative which follows, those opening shots of the prison do not (Renton 44).

These shots can only be understood in retrospect at the very end of the film.

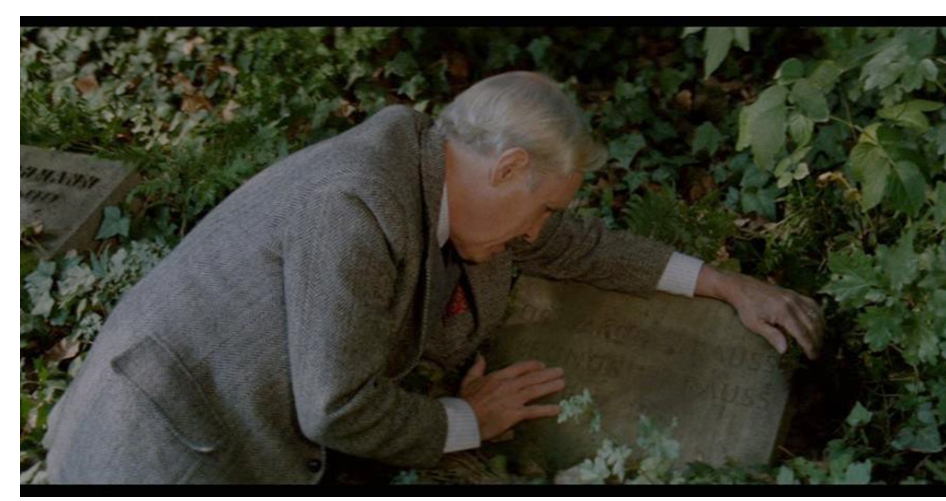

Illustration 5: Henry/Hans at his parents' grave

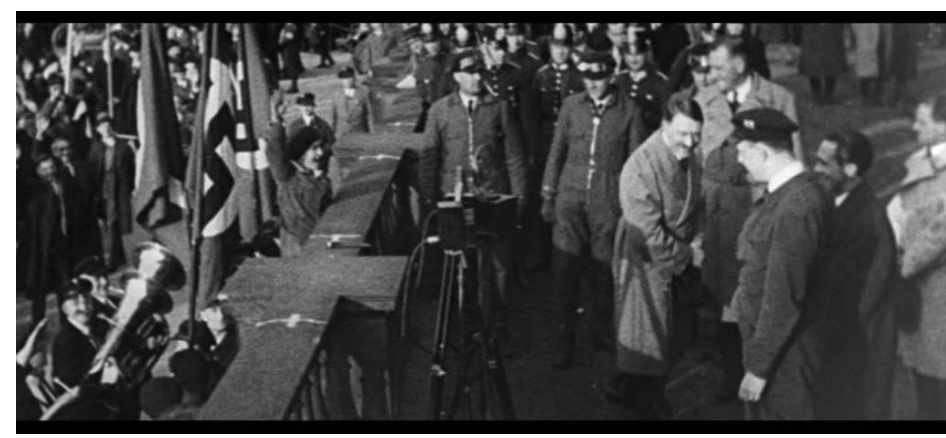

Illustration 6: Summer of 1932: Hitler's arrival in Berlin. Vast crowds greeting him (archive material, black and white)

Images of Henry's present and some of the darkest moments of the Nazi past of Germany are also intertwined, as when the shots from Henry in the cemetery, looking for his parents' grave, are cut and interrupted by scenes from the trial of the defendants in the July 1944 plot to kill Hitler (606-7, see illustrations 5 and 6). Moreover, intermittently through the screenplay, "flashes of personal memory or public images of moment" - like the montage the summer of 1932 in Germany, made of stock shots, in 
sepia tones like "Hitler's arrival in Berlin; Vast crowds greeting him" or "Couples dancing" in a train or "Newsreel in cinema: Communist demonstrations against Fascism" (588, illustrations 7, 8 and 9) - are used to supplement the narrative, endowing the image with greater significance than that of mere object or event." "This technique complements the scene in the Stuttgart warehouse, in which Henry confronts the fragments of memory and history, a Germany he shut from his mind fifty-five years ago" (Knowles 171): each of the object he unpacks ("a long-stemmed wine glass, blue Meissen plates, a Jewish candlestick" 546), will later be seen in context, so to speak, in the dining-room of the family house.

To make the story more dynamic and filmic, and keeping in mind the fact that Uhlman was not a native English speaker, Pinter rewrote most of the existing dialogues: "he didn't think the dialogue was right. The way he put it, 'It was from another world,"' the director remembers (qtd. in Gauthier, Viva Pinter 69). He also dramatizes the letter Konradin writes to Hans just before he leaves for New York (Uhlman 101-3) in a typical "Pinteresque" way, with pauses and silence being as important as what is actually being said:

\section{EXT. STREET. EVENING.}

Hans walking up the hill. Konradin steps out of a doorway.

Hans stops. Konradin comes towards him.

KONRADIN: When are you going?

HANS: Tomorrow.

Pause.

KONRADIN: I'm sorry it's come to this. But it probably makes sense - just for the time being. The country will be in a state of flux for a while, I should think. But the fact is we want a new Germany and we're going to get it.

Hans looks at him, expressionless.

Listen... I want to tell you... I believe in Hitler. I met him in Munich recently. He really impressed me. He's... totally sincere, you see. He has such... He has true passion. I think he can save our country. He's our only hope.

Hans stands staring at him.

Look. I'm sure that in a couple of years you'll be able to come back. Germany needs people 

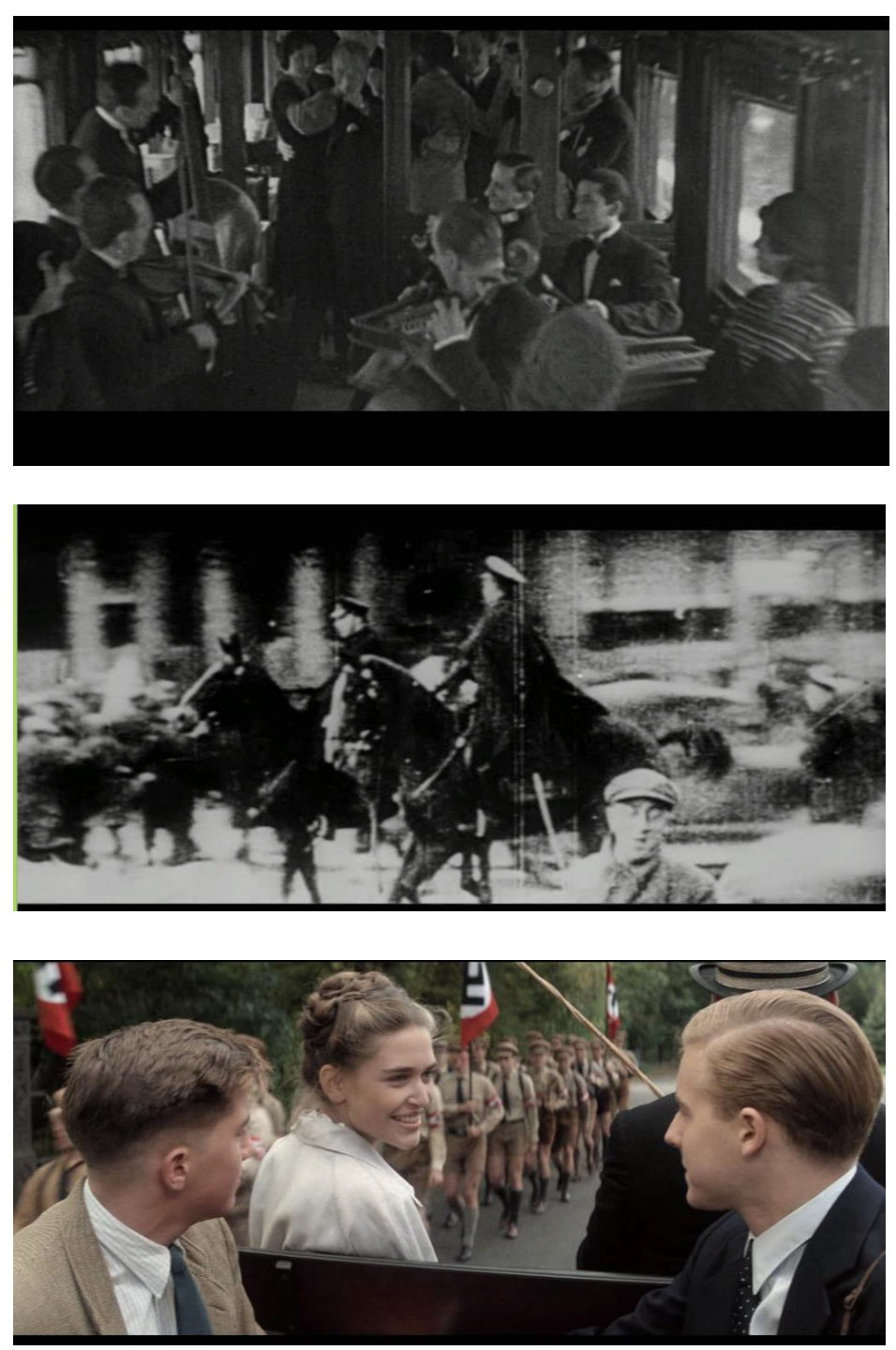

Illustration 7: Summer of 1932 Couples dancing in a train (archive material, black and white)

Illustration 8: Summer of 1932 Newsreel in cinema: Communist demonstrations against Fascism (archive material, black and white)

Illustration 9: 1932: Gertrude (18): "Aren't they (the Hitler Youth boys) handsome?" 
like you. I'm sure that the Führer will be willing to choose between the good Jewish elements and the... undesirable Jewish elements.

(Pause)

I’ve learnt so much from you, you know. You've taught me to think. You have. Truly.

(He extends his hand.)

Good luck.

Hans does not take his hand. They stand still. Hans turns away and runs up the hill. Konradin opens the gates and goes in. (594-595)

Pinter's structural changes also altered the narrative focus. Whereas the novella is clearly centred on Konradin as Hans describes his life from the moment Konradin walks into his schoolroom, Pinter on the other hand "humanize[s] the tale by focusing on Hans/Henry" (Gale 306) as he returns to Germany. He plays a much more active role in the narrative present in his quest for the truth about his lost friend but also about 1980s Germany, an aspect which is totally absent from the novella.

Making Hans/Henry return to Germany meant adding a great number of fictional characters, from the hotel receptionist, the taxi driver etc., to the headmaster of the Karl Alexander high school. However, a historical character was also added: Judge Roland Freisler, President of the People's Court (Volksgerichtshof) from 1942 to 1945, who appears several times throughout the film in different scenes, all shot in black and white. Freisler headed the 1943 proceedings against the members of the White Rose resistance group as well as the participants in the July 20th plot against Hitler in 1944 and ordered many of them to be executed. He was known for humiliating defendants and shouting at them. A number of the trials before the People's Court were filmed and recorded for propaganda purpose. However, Pinter and Schatzberg did not use archive footage (as they did elsewhere in the film) but recreated the setting of the People's Court, with an actor (Roland Schäfer) playing Freisler. ${ }^{3}$ The presence of this historical figure from the darkest days of the German past serves as a reminder of the

3 Schatzberg himself explains his choice: «Il y a beaucoup de documents d'époque sur [Freisler] mais nous l'avons fait jouer par un acteur car nous voulions qu'il utilise notre texte et je désirais avoir le contrôle de ses interventions. » (Ciment, « Trois rencontres avec Jerry Schatzberg » 12) 
true nature of the Nazi regime which, according to Pinter, contemporary Germans like the taxi-driver Henry/Hans yells at, who as "a man in his sixties" (603) was clearly of age during the war, want to forget. By using a double time frame and "by pointedly juxtaposing the Nazi and post-war periods, Pinter engages controversial and sensitive issues surrounding Germany and the Holocaust" (Grimes, Harold Pinter's Politics 167). For as Pinter said in an interview with Michel Ciment,

what is left of the Nazi past is tangible in some respects, shadowy in others, possible in yet other respects, or simply nonexistent among some of the young. But on the whole, I don't think they have really managed to overthrow the past. Because let's face it, it's probably the strongest imaginable in the impact on the consciousness of the people; no wonder it can't be erased too easily (qtd. in Grimes, Harold Pinter's Politics 167-8).

And as he had said in an earlier interview, "I don't think we'll ever get to the bottom of the actual guilt, of the actions of the German people. But there is also the question of complicity" (Davis 15). In an earlier screenplay, The Quiller Memorandum (1966), Pinter had already addressed the resurgence of Nazism in Germany in the 1960s. Twenty years later, in Reunion, this is clearly still a concern. It is embodied by Konradin's cousin Gertrude, countess von Zeilarn und Lizen. When Hans is introduced to her by Konradin in 1932, she is a young woman ("Gertrude 18," 572), and she already exhibits the signs of Nazi indoctrination. Not only does she think that Hitler Youth boys are handsome (572, illustration 7), but also that the Nazis "have the good of Germany at heart" and that "it's all pretty exciting" (575). She is also anti-Semitic, like her parents $(574,575)$. Then, when, on his return to Germany fifty-five years later, he meets her again ("a tall woman in her early seventies. She stands erect," 600) and tries to find out what has happened to Konradin, not only does she icily refuse to answer his question (see quotation above), but she characterizes the 1930s as "wonderful days" (601, illustration 8). Her open and to a certain extent honest refusal to acknowledge the horrors of Nazism and even more to feel any form of guilt for what happened before and during the war exemplify the fact that some of her contemporaries as well as the post-war Germans portrayed in the script (the taxi-driver, for example) are still in denial of their past, which therefore cannot be laid to rest.

For some critics, like Brigitte Gauthier, "with Reunion, it is as if Pinter chose to pay his duty to his own [Jewish] culture" (The Caretaker of the Fragments of Modernity 17). It is true that, in the screenplay, he added a discussion between Konradin and Hans about the so-called "Jewish problem" (585-7). And of course for him "the Holocaust is actually the most appalling thing that has ever happened" (Davis 15). This point of view is however widely shared by historians and critics alike. Moreover, Pinter's 


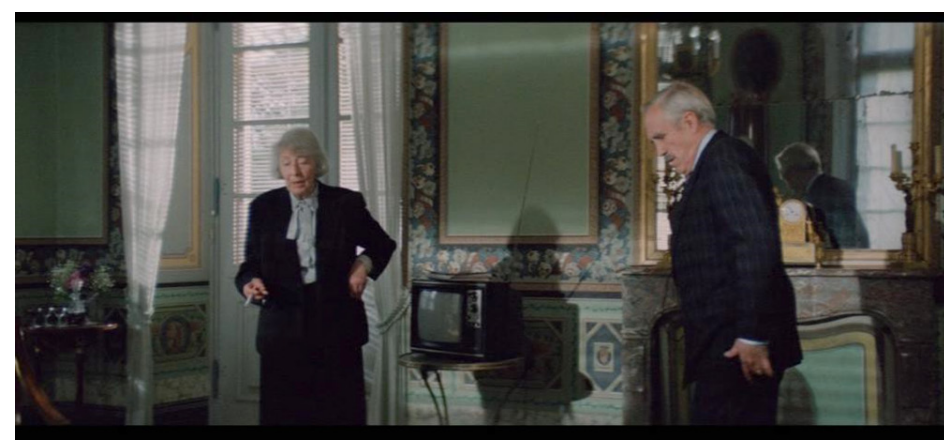

Illustration 10: 1987: Gertrude (73): the 1930s were "wonderful days!"

relationship with the religion of his birth was peripheral at best (like Hans's parents in the novella and the film) and from his early adulthood he consistently considered himself an atheist and a secular writer (Roblin 176-8). Brigitte Gauthier herself remarked a few years later: "his work is not turned towards memories of our past, however traumatic it may be, but towards a clear and

present danger: the erosion of democratic values" (Viva Pinter 1).

The fact that Konradin is, in the novella as well as the screenplay and the film, eventually executed for taking part in the 1944 plot against Hitler led by Colonel Claus von Stauffenberg can be interpreted in different ways. For Ronald Knowles for example, "there is a degree of mitigation in Konradin's act. His sacrifice not only atones for the betrayal of friendship but symbolically atones for the larger self-betrayal of Germany. Hans and Konradin's early trust is vindicated, and the darkness of fascism could not extinguish truth for all Germans" (171). Charles Grimes goes even further, writing that "the surprise ending of both the novel and the film, revealing Konradin to have been one of the conspirators in the July 20, 1944, assassination plot, has the effect of mitigating German guilt for Hitler's atrocities" (Harold Pinter's Politics 171). For my part, I do not agree with such analyses, which I think go too far in seeing in Konradin a sort of Christ-like figure dying a horrible death to atone for the sins of his country and his countrymen (Grimes even writes about "Konradin's gesture of martyrdom" 174, my italics). As Schatzberg himself said, "there are many great films about the Holocaust, but not the film I did. It's a film about friendship" (qtd. in Gauthier, Viva Pinter 71). Konradin writes at the end of his final letter to Hans: "You have had a great influence in me. You have taught me to think, and to doubt" (Uhlman 103; slightly modified in the published script: "I've learnt so much from you, you know. You've taught me to think. You have. Truly" 595). It is tempting to imagine that the adult Konradin has eventually put to use this capacity to think and doubt, - doubt being according to Descartes the methodological basis of philosophy - to get over his teenage infatuation with Hitler and Nazism and knows the evil nature of their ideology. As the French title of the novella, L'Ami retrouvé, indicates, 
Henry/Hans, once the shock of the knowledge of Konradin's death abates, might be able to look back on his friendship with Konradin as something to be valued and cherished, rather than a painful memory. As Linda Renton writes, "the friendship between Hans and Konradin [is] restored in the knowledge of Konradin's sacrifice and intensified by his loss" (47). In this sense, the ending of both the novel and the film can be construed as optimistic in so far as the two friends can indeed, albeit belatedly, be reunited.

In his introduction to the novella, Arthur Koestler calls it "a minor masterpiece," minor referring "to the small size of the book" (7). However, by all accounts, Jerry Schatzberg's film was not very successful in terms of audience. Pinter himself claimed that the film was "very underated" (introduction to the Collected Screenplays 2 viii). When it came out in New York, it only ran for a few days and it is still today virtually unknown in the United States, its director's country of origin. For his part, the French cinema critic Michel Ciment tried to explain this fact and pointed out:

It is very sad that the film did not have a very long run. It did quite well in France. It was shown at the Cannes film festival (in 1989); it would seem that Wim Wenders [who presided the jury] as a German was quite annoyed by the film and that he hadn't liked it very much. (in Gauthier, Viva Pinter 81)

Michael Billingham, Pinter's biographer, wrote that "the film [...] seemed to pass as if nothing had happened." He adds: "Which is curious, since [...] it deals with a subject of enormous resonance: not only the rise of National Socialism in Germany in the 1930s, but also with the schizophrenia in the German soul that allowed one of the most historically cultured nations on earth to descend into barbarism" (315). So the film's release in DVD format in France in 2014, twenty-five years after it was shot, might hopefully signal a renewed interest in this "quiet film," "less grandstanding" but nonetheless at least "as passionate and affecting" as, for example, Spielberg's 1994 Schindler's List (Gale 312). Samuel Blumenfeld's review in Le Monde, which hailed it as an extraordinary achievement, rigorous, very moving and at the same time devoid of any sentimentalism, $(8)^{4}$ does justice to Pinter and Schatzberg's craftsmanship, which is also, in its own way, "a minor masterpiece."

4 Blumenfeld praises «'extraordinaire réussite du film, rigoureux, bouleversant, et se détachant de tout sentimentalisme », 8. « Pour Pinter, l'un des problèmes était précisément d'éviter le sentimentalisme, tant dans la représentation de l'amitié entre les deux garçons que dans celle de la souffrance des personnages » (Ciment, « Entretien avec Harold Pinter » 24-25). 


\section{BIBLIOGRAPHY}

BILLINGTON, Michael. The Life and Work of Harold Pinter. 1996. London: Faber and Faber, 1997.

BLUMENFELD, Samuel. «Le temps passé ». Le Monde-Télévisions. 18-19 mai 2014. 8.

CIMENT, Michel. «Trois rencontres avec Jerry Schatzberg ». Positif n³39, 1989. 5-14. . «Entretien avec Harold Pinter ». Positif, n³39, 1989. 23-27.

DAVIS, Barry. "The 22 from Hackney to Chelsea: A Conversation with Harold Pinter." The Jewish Quarterly Winter 1991-1992. 9-17.

FINK, Guido. « Pinter et le cinéma: une présence dans le noir. ». Translated from the Italian by Paul-Louis Thirard, Positif n³39, 1989. 15-21.

GALE, Steven. "Reunion." Sharp Cut. Harold Pinter's Screenplays and the Artistic Process. Lexington: The University Press of Kentucky, 2003. 301-314.

GAUTHIER, Brigitte. Harold Pinter. The Caretaker of the Fragments of Modernity. Etude de l'œuvre de Pinter. Paris: Ellipses, 1996.

, ed. Viva Pinter. Harold Pinter's Spirit of Resistance. Bern: Peter Lang A.G., 2009.

GRIMES, Charles. Harold Pinter's Politics. A Silence Beyond Echo. 2005. Cranbury, NJ: Fairleigh Dickinson University Press, 2007.

. "Process and History in Harold Pinter's Reunion Screenplay," The Pinter Review. University of Tampa Press. Annual Essays 2003-2004. Vol. 11, 2004. 144-155.

GUSSOW, Mel. Conversations with Pinter. 1971-1993. 1994. New York: G rove Press, 1996.

KNOWLES, Ronald. "Reunion." Understanding Harold Pinter. Columbia: University of South Carolina Press, 1995. 169-172.

MASSON, Alain. «Le passé réuni (L’Ami retrouvé) ». Positif n³39. 1989. 3-4.

PINTER, Harold. Screenplay of Fred Uhlman's Reunion, dated February 22, 1988. British Library: ADD MS88881/8/14

. "Reunion." Collected Screenplays 2. London: Faber and Faber, 2000. 533-609. . Various Voices. Prose, Poetry, Politics 1948-2005. London: Faber and Faber, 2005.

PRENTICE, Penelope. The Pinter Ethic: the Erotic Aesthetic. New York: Garland Publishing, 2000.

RENTON, Linda. "Reunion", in Pinter and the Object of Desire. An Approach through the Screenplays. Oxford: Legenda, 2002. 44-47.

ROBLIN, Isabelle. Harold Pinter adaptateur: la liberté artistique et ses limites. Approches des scénarios. Paris: l'Harmattan, 2011.

SCHATZBERG, Jerry, dir. L'Ami retrouvé [Reunion]. 1989. Screenplay by Harold Pinter. TF1 vidéo, 2014.

UHLMAN, Fred. Reunion. 1971. Introduction by Arthur Koestler (June 196). Harmondsworth: Penguin, 1978. . L'Ami retrouvé. 1971. Translated into French by Léo Lack. Dossier et notes Marie-Sophie Doudet. Paris : Folioplus classiques, 2005 


\section{List OF ILLUSTRATIONS}

Illustration 1: While playing in Central Park, Henry's young grand-daughter Alex is charged by a large German Shepherd.

Illustration 2: 1932, Henry's father, standing at attention in his WWI uniform, next to a member of the SS holding an anti-Jewish placard in his right hand and a fierce-looking German Shepherd on leash in the other (black and white).

Illustration 3: opening shot: the execution room (black and white)

Illustration 4: final shot: the empty execution room (colour)

Illustration 5: Henry/Hans at his parents' grave

Illustration 6: Summer of 1932: Hitler's arrival in Berlin. Vast crowds greeting him (archive material, black and white).

Illustration 7: Summer of 1932 - Couples dancing in a train (archive material, black and white)

Illustration 8: Summer of 1932 - Newsreel in cinema: Communist demonstrations against Fascism

Illustration 9: 1932: Gertrude (18): “Aren't they (the Hitler Youth boys) handsome

Illustration 10: 1987: Gertrude (73): the 1930s were "wonderful days!" 